\title{
Heat and Velocity Parameters of a Non-Isothermal Flow Generated by a Double-Chamber Air Diffuser
}

\author{
Hanna Klymenko \\ National University "Lviv Polytechnic" \\ Institute of Building and Environmental Engineering, Chair "Heat, Gas supply and ventilation" \\ e-mail: anett64@gmail.com
}

\begin{abstract}
Heat and velocity parameters of the non-isothermal flow generated by a source panel-type double-chamber air diffuser with four horizontal shelf pressure equalizers of optimal relative length at the mid-horizontal level and in the vertical axisymmetrical plane. Irregularity ratios of initial velocities and temperatures of the air flow under study have also been defined.
\end{abstract}

Key words: displacement ventilation, panel-type air diffuser, horizontal shelf pressure equalizers, temperature, velocity

\section{Introduction}

The movement of indoor air is one of the most important parameters which affect our feeling of comfort. In the practice of ventilation, ejection-mixing air distribution is most common. Such air distribution is ensured by ventilation systems of the "Mixing ventilation" type. It may be used in places with surplus or insufficient heat as well as the concurrent emission of other pollution agents.

It is not always possible to ensure standard and regular indoor air thermal and hygienic parameters within the serviced area or its separate cubes with the help of the ejection mixing of prepared inflow air with more polluted indoor air. Indoor air regular temperature and pollution agent concentration can be ensured only in conditions of full mixing air distribution within all indoor airspace. However, in order to meet standard thermal and hygienic parameters of the indoor air, extensive air exchange is required, which leads to low cost effectiveness of ventilation systems.

Therefore, with raised demands to thermal and hygienic parameters of the serviced area indoor air, it is reasonable to "flood" the serviced area directly with prepared cool inflow air. 
For this purpose, ventilation systems of "Displament ventilation" type are used. The functioning of such systems is ensured by air diffusers which make the indoor air flow bottom-upwards. With such air distribution, the air current flows from large-surface filter air diffusers without vortex (laminar or low-turbulence outflow) into the service area or the working space.

\subsection{Problem}

For "flooding" the service area, source air diffusers of various types are used $[4 ; 5 ; 6]$, including panel-type ones, mostly one-chamber. Separate aerodynamic features of onechamber panel-type air diffusers are given in paper [1]. In general, however, air diffusers of this type, particularly double-chamber ones, are studied insufficiently. No research results on heat and velocity parameters of currents generated by source double-chamber air diffusers are currently available.

\subsection{Research Aim}

The aim of this study is to research velocity and temperature distribution in the air flow (air current) generated by a source round-hole perforated air diffuser with four horizontal shelf pressure equalizers in the primary pressure chamber [10] and to define air current initial velocity and initial temperature irregularity ratio.

\subsection{Research Object}

The object of the research is a patented and released source panel-type double-chamber single-section air diffuser, uniformly round-hole perforated (free area ratio $k_{f a}=0.32$ ), with horizontal shelf pressure equalizers of optimal length in its primary pressure chamber [11].

\section{Field Research Features}

An air diffuser of a shopfloor general input system of ventilation (Fig. 1) has been used in field research. Its mockups were built by analogy with the air diffuser scaled model previously studied in a laboratory environment [12]. The general view of air diffuser mockups with one-side and two-side air outflow is shown in Fig. 1, and the structural scheme of the air diffuser under study with a one-side air outflow is given in Fig. 2. 


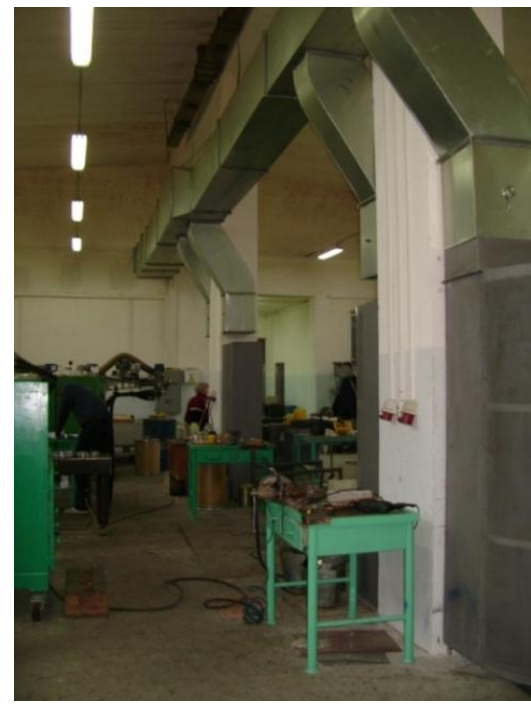

Figure1: General view of an input system of ventilation with source double-chamber round-hole perforated air diffusers
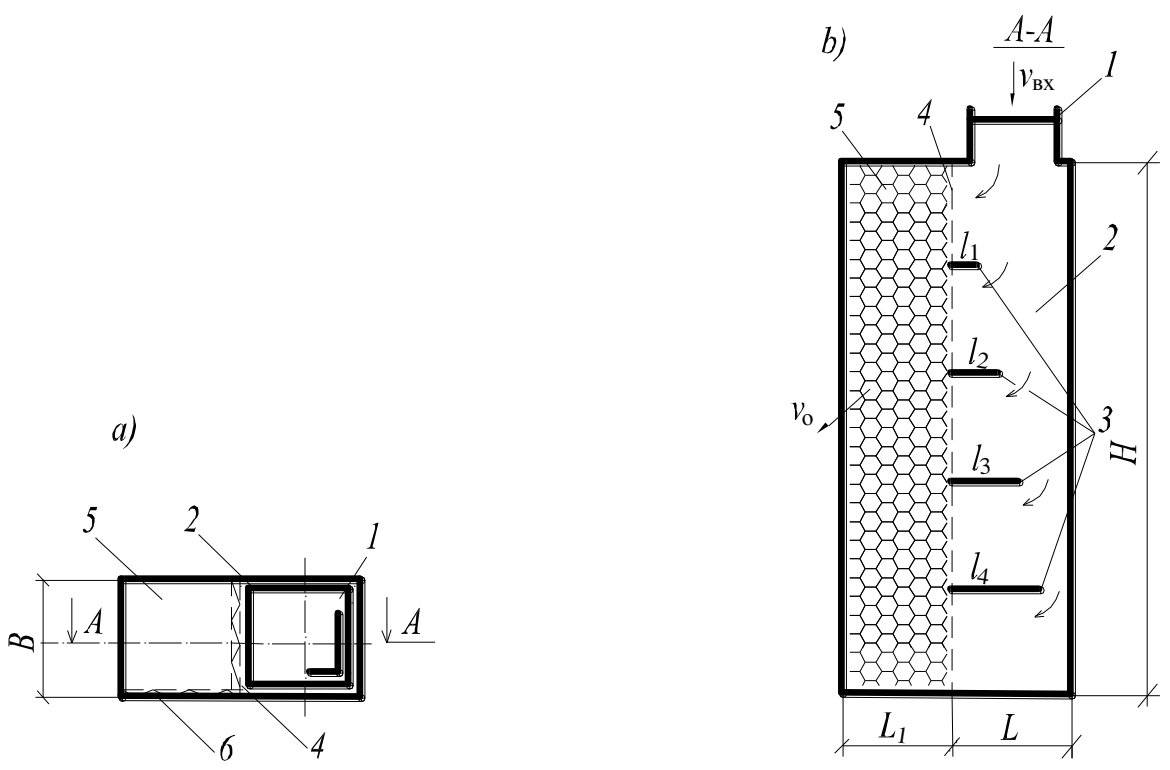

Figure 2: Structural scheme of a source panel-type double-chamber single-section air diffuser, uniformly round-hole perforated, with horizontal shelf pressure equalizers:

a-plane view; b-view along A-A;1-suction nozzle; 2- primary pressure chamber; 3 - horizontal shelf pressure equalizers; 4-inner perforated wall; 5 - secondary pressure chamber; 6-air diffuser perforated wall; $L$ - primary pressure chamber length; $L_{1}$ - secondary pressure chamber length; $B$ - air diffuser width; $\bar{l}_{i}=l_{i} / L$ - relative length of $1^{\text {st }}$ horizontal shelf pressure equalizer

Research scheme is presented in Fig. 3. 


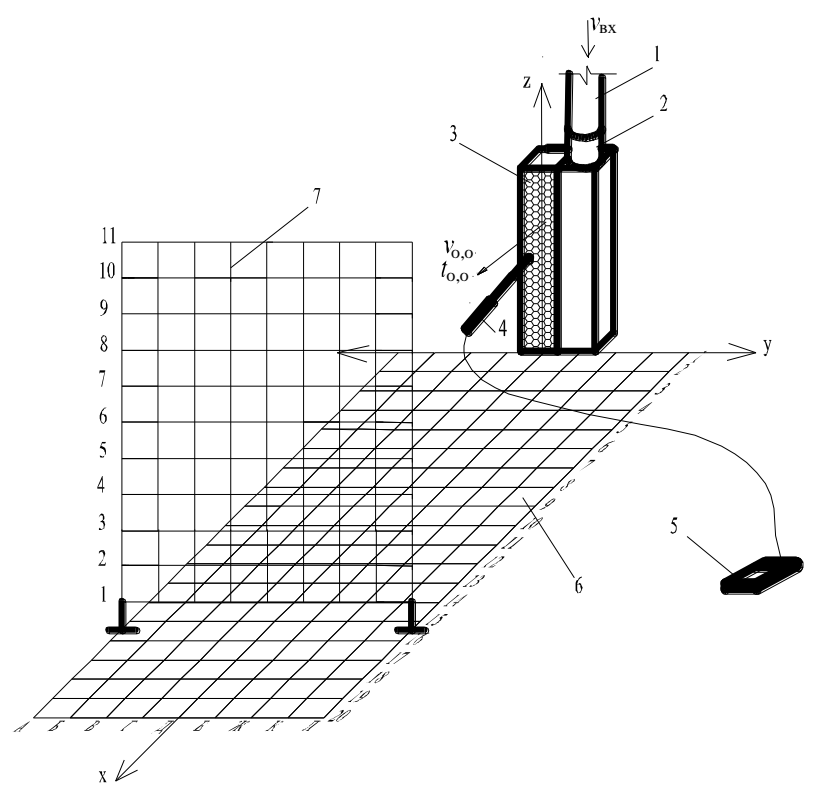

Figure 3: Research scheme of studying velocities and temperatures in the non-isothermal flow (air current) generated by a source double-chamber air diffuser with one-side air outflow: 1- air channel of the input system of ventilation; 2- suction nozzle;

3- front perforated wall of the air diffuser; 4- heat loss anemometer probe, 5- heat loss anemometer «Testo-405»; 6-horizontal-plane coordinate spacer; 7- vertical-plane coordinate spacer

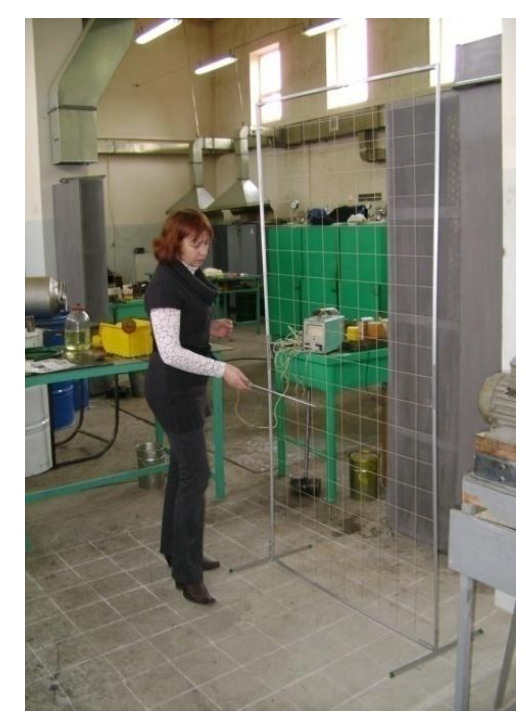

Figure 4: In the course of carrying out field research

The air flows with the velocity $v_{\text {input }}$ from air channel 1 through the suction nozzle 2 into the pressure equalizer chamber and flows out through the front perforated wall 3 of the singlesection one-side air-permeable secondary chamber into the serviced area of the indoors with a 
certain initial temperature $t_{0,0}$ and velocity $v_{0,0}$. Midpoint velocities $v_{x, y}$ and temperatures $t_{x, y}$ of the air flow at certain levels $z$ have been measured due to probe 4 of the heat loss anemometer 5. Horizontal-plane coordinate spacer 6 and vertical-plane coordinate spacer 7 have been used for defining the measurement location of point velocities $v_{x, y}$ and temperatures $t_{x, y}$ of the air flow.

Measuring instruments used in research are given in Table 1.

Table 1: Measuring Instruments

\begin{tabular}{|l|l|l|}
\hline Item & \multicolumn{1}{|c|}{ Measuring instrument name } & \multicolumn{1}{|c|}{ Characteristics } \\
\hline 1 & Aneroid barometer BAMM-1, № 9132 & $\begin{array}{l}8 \ldots 106 \mathrm{kPa} ; \\
\text { accuracy } \pm 200 \mathrm{~Pa}\end{array}$ \\
\hline 2 & Thermometer № 20922 & Accuracy $\leq 0.1^{\circ} \mathrm{C}$ \\
\hline 3 & $\begin{array}{l}\text { Thermoelectroanemometer } \\
\text { Testo-405 }\end{array}$ & Accuracy $\pm 0.1 \mathrm{~m} / \mathrm{s}$ \\
\hline
\end{tabular}

\section{Research Results and Discussion}

The research of initial velocities $v_{0,0}$ and temperatures $t_{0,0}$ of the air flow has been done in the horizontal-plane coordinates $x, \mathrm{y}$ at five different levels $z$.

The irregularity ratio of initial velocities of the air flow has been defined according to the formula:

$$
\varphi_{v 0}=v_{0,0} / v_{0,0 \max }
$$

where $v_{0,0}$ - initial point velocities of the air flow along vertical $z$ with coordinates $x=0, \mathrm{y}=0 ; v_{0,0 \max }$ - maximum initial velocity of the air flow in one of this vertical's points. Numerically, the value of $\varphi_{v 0}$ is 0.88 .

The irregularity ratio of initial temperatures of the air flow was defined according to the formula:

$$
t_{v 0}=t_{0,0} / t_{0,0 \max }
$$

where $t_{0.0}$ - the average initial temperature of the air flow in vertical $z$ at coordinates $x=0, \mathrm{y}=0 ; t_{0,0 \max }$ - maximum initial velocity of the air flow in one of the points of this vertical. The numeric value of $\varphi_{t 0}$ is 0.96 .

Results of the study of horizontal-plane velocities at level $\bar{z}=0,53$ are presented in Fig. 5 in relative coordinates $\bar{x}, \bar{y},(\bar{x}=x / H ; \bar{y}=y / H ; \bar{z}=z / H$, where $H$ - air diffuser height, $\mathrm{m})$, dimensionless isotachs (lines which join points with equal air flow velocity value) $\bar{v}_{100}, \bar{v}_{70}, \bar{v}_{50}, \bar{v}_{30} \quad$ (for example, $\bar{v}_{70}=0.7 \cdot 100 ; 0.7-$ the value of relative velocity 
$\bar{v}_{x, y}=v_{x, y} / v_{0}$, where $v_{x, y}$ - point velocity in the flow point with horizontal-plane $x, \mathrm{y}, \mathrm{m} / \mathrm{s}$; $v_{0}$ - initial velocity of the flow, $\mathrm{m} / \mathrm{s}$ ).

Fig. 5 shows the configuration of isotachs of air diffuser - generated sizeless air flow and allows stating that the flow core zone covers the distance $\bar{x} \cong 0.05$; isotach $\bar{v}_{70}$ covers the distance $\bar{x} \cong 0.38$; isotach $\bar{v}_{50}$ - the distance $\bar{x} \cong 0.98$ and $\bar{v}_{30}$-the distance $\bar{x} \cong 1.27$. The maximum width of the flow within $\bar{v}_{50}$ does not exceed 2 widths of the air distribution wall (Fig. 5).

Results of the study of horizontal-plane temperatures at level $\bar{z}=0.53$ are p[resented in Fig. 6 in relative coordinates $\bar{x}, \bar{y}$, as relative temperature differences $\Delta \bar{t}_{100}, \Delta \bar{t}_{70}, \Delta \bar{t}_{50}, \Delta \bar{t}_{30}$ (for example, $\Delta \bar{t}_{70}=0.7 \cdot 100 ; 0.7$ - the value of relative temperature difference $\Delta \bar{t}=\Delta t_{x, y} / \Delta t_{0}$, where $\Delta t_{x, y}$ - temperature difference between the flow and the environment (indoor air temperature $t_{\text {indoor,dif }},{ }^{0} \mathrm{C}$ ) in the point with coordinates $\bar{x}, \bar{y} ; \Delta t_{0,0}$ - difference between air flow initial temperature and environment temperature $t_{\text {indoordif }},{ }^{0} \mathrm{C}$ ).

Fig. 6 shows the configuration of isotherms of the air diffuser -generated non-isothermal air flow and also allows stating that the flow (current) core zone covers the distance $\bar{x} \cong 0,05$; relative temperature difference $\Delta \bar{t}_{70}$ - the distance $\bar{x} \cong 0.34 ; \Delta \bar{t}_{50}$ - the distance $\bar{x} \cong 0.68$ and $\Delta t_{30}$ - the distance $\bar{x} \cong 1.1$. The maximum width of the flow within $\Delta \bar{t}_{50}$ does not exceed 2 widths of the air distribution wall.

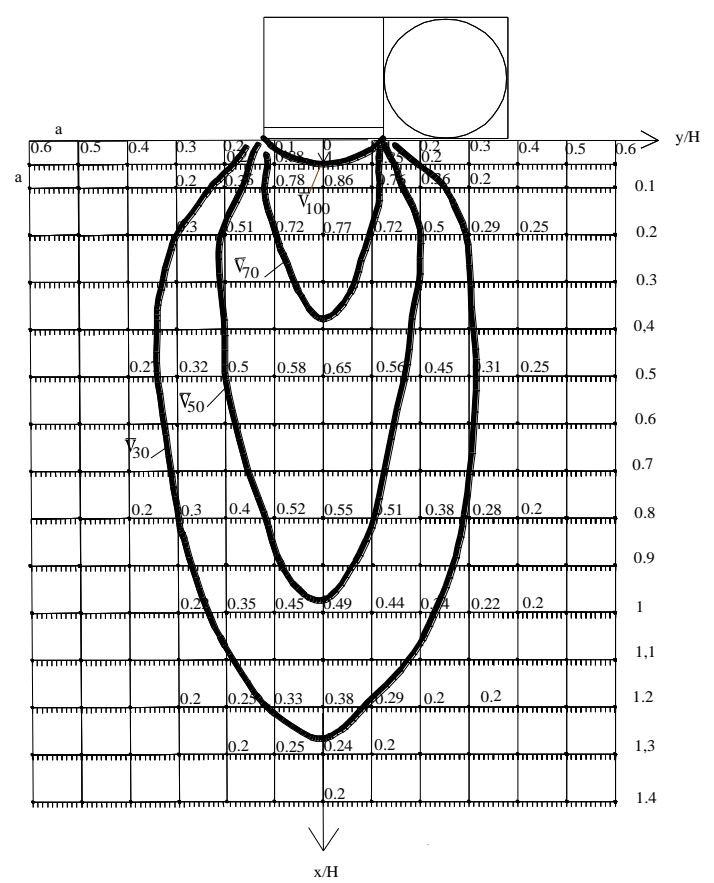

Figure 5: Velocity epures $\bar{v}_{100} \bar{v}_{70}, \bar{v}_{50}, \bar{v}_{30}$ at level $\bar{z}=0.53(\bar{z}=z / H)$ 


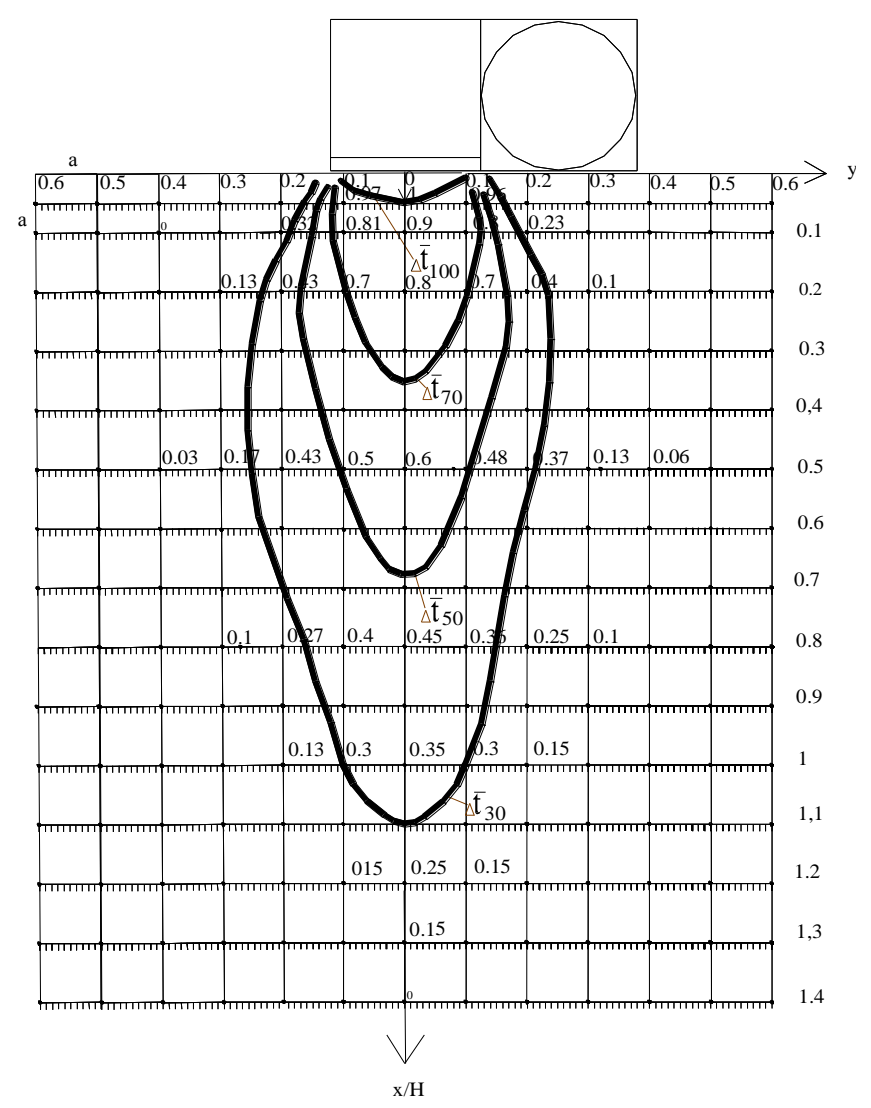

Figure 6: Relative temperature differences $\Delta \bar{t}_{100} \overline{\Delta t}_{70}, \Delta \bar{t}_{50}, \overline{\Delta t}_{30}$ at level $\bar{z}=0.53(\bar{z}=z / H)$

Fig. 7 shows the distribution of relative velocities $\bar{v}_{100}, \ldots, \bar{v}_{30}$ in the vertical-plane coordinates $\bar{x}, \bar{z}$ at $y=0$, within levels $\bar{z}=0.0 \ldots 1$, and Fig. 8 shows the distribution of relative temperature difference $\Delta \bar{t}_{100}, \ldots, \Delta \bar{t}_{30}$ in the vertical-plane coordinates $\bar{x}, \bar{z}$ at $y=0$, within levels $\bar{z}=0.0 \ldots 1$.

Fig. 7 and Fig. 8 show that air diffuser -generated air flow is rather stagnated at the lowest level by the floor and at the highest level by the "conventionally motionless" surrounding air. The highest relative velocities of the flow $\bar{v}_{x, z}$ are observed at its middle altitude level, i.e. at $\bar{z}=0.5$. Relative temperature differences $\Delta \bar{t}_{x, z}$ are the greatest at this level too. 


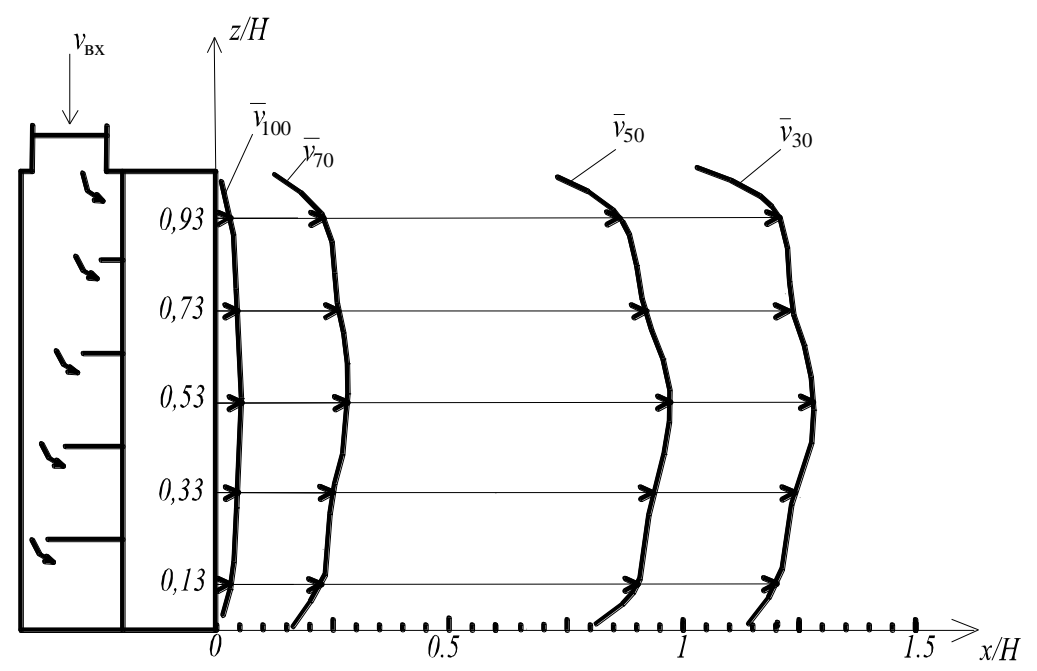

Figure 7: Sizeless vertical-plane isotachs $\bar{v}_{100}, \ldots, \bar{v}_{30}$ within levels $\bar{z}=0.0 \ldots 1$ at distance $\bar{x}=0 \ldots 1.5$ from diffuser at $\bar{y}=0$

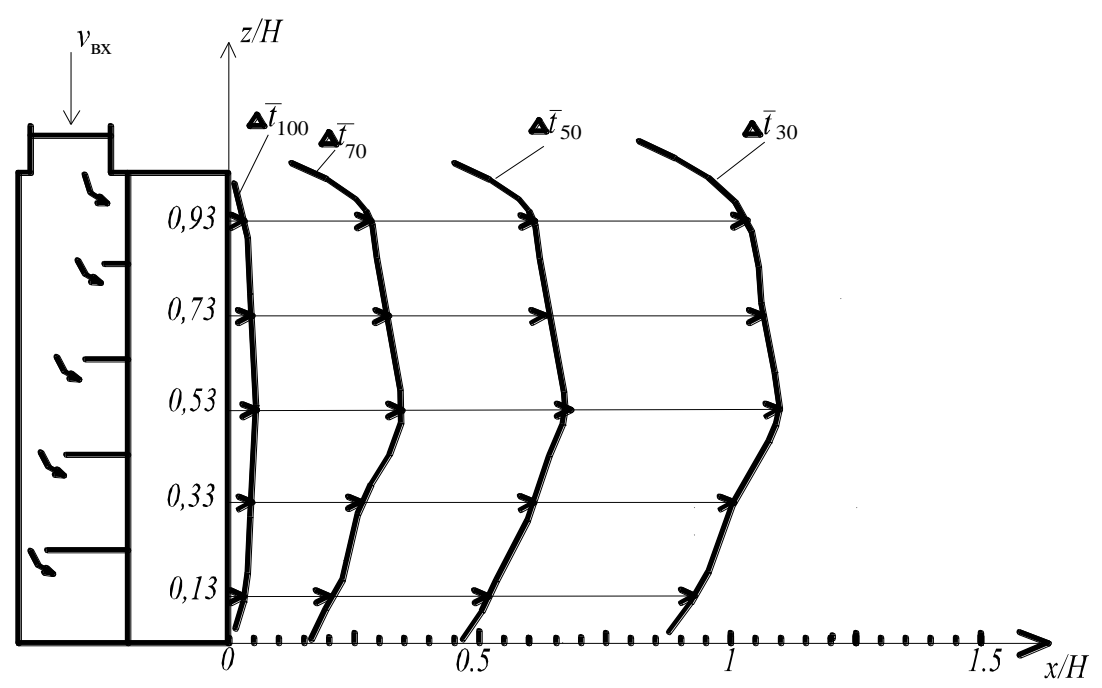

Figure 8: Sizeless temperature differences $\Delta \bar{t}_{100}, \ldots, \Delta \bar{t}_{30}$ within levels $\bar{z}=0.0 \ldots 1$ at distance $\bar{x}=0 \ldots 1.5$ from air diffuser at $\bar{y}=0$

On the basis of research results curves of relative maximum velocity $\bar{v}_{x, y \max }$ change and relative temperature difference $\overline{\Delta t}_{x, y \text { max }}$ change in horizontal-plane coordinates $x, y$ in the non-isothermal air flow generated by a source double-chamber round-hole perforated air diffuser have been created (Fig. 9). 


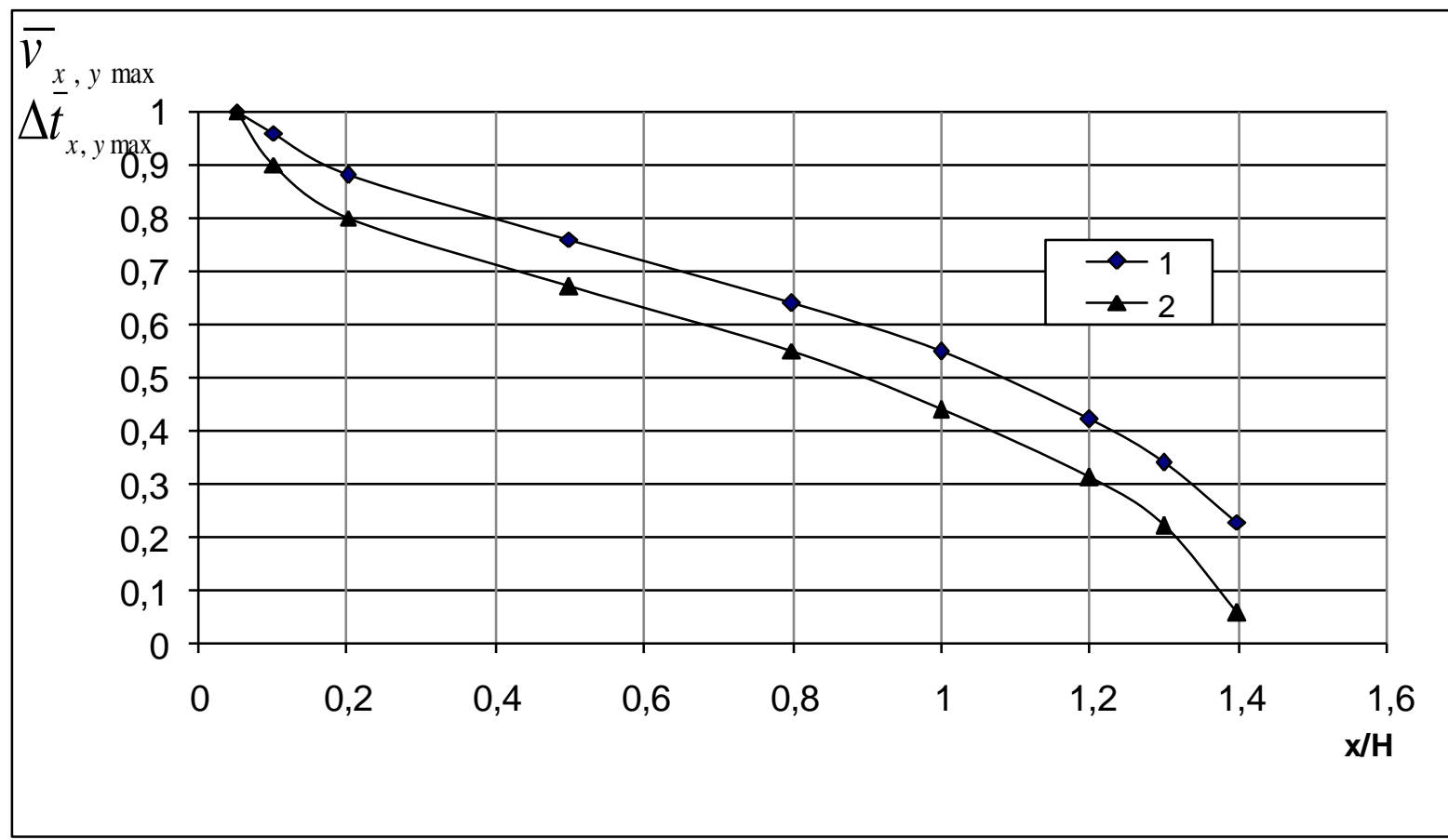

Figure 9: Curves of relative maximum velocity $\bar{v}_{x, y \text { max }}$ change (1) and relative maximum temperature difference $\overline{\Delta t}_{x, y \text { max }}$ change (2) in the non-isothermal air flow generated by a source double-chamber round-hole perforated air diffuser

The value of relative maximum velocity $\bar{v}_{x, y \max }=v_{x, y \max } / v_{0,0}$, where $v_{x, y \max }$ - the value of point velocity in the flow at distance $\bar{x}$ from air diffuser at $\bar{y}=0$ at level $\bar{z}=0.53 ; v_{0,0}$ the velue of initial velocity of the flow at the same level $\bar{z} ; \overline{\Delta t}_{x, y \max }=\Delta t_{x, y \max } / \Delta t_{0,0}-$ the value of relative temperature difference, where $\Delta t_{x, y \max }-$ the difference between maximum and point temperature in the air flow at distance $\bar{x}$ from air diffuser at $\bar{y}=0$ at level $\bar{z}=0.53$ and the temperature of the environment (that of the indoor air), ${ }^{0} \mathrm{C} ; \Delta t_{0,0}$ - the difference between initial temperature of the air flow and environment temperature $t_{\text {indoor }, i f},{ }^{0} \mathrm{C}$.

\section{Conclusion}

1. At horizontal-plane level $\bar{z}=0.53(\bar{z}=z / H$, where $H$ - the height of air distribution wall of the air diffuser) non-dimensional isotachs $\bar{v}_{100}, \bar{v}_{70}, \bar{v}_{50}, \bar{v}_{30}$ and sizeless temperature differences $\overline{\Delta t}_{100}, \overline{\Delta t}_{70}, \Delta \bar{t}_{50}, \Delta \bar{t}_{30}$ have been defined which provide evidence of the 
configuration and parameters of the air flow generated by a four-horizontal-shelf panel-type source air diffuser with optimal lengths of static pressure equalizers, namely: air flow (air current) core zone covers the distance $\bar{x} \cong 0.05$; air flow length within $\bar{v}_{50}$ and $\Delta \bar{t}_{50}$ does not exceed $2.5 \bar{x}$ and its width is less, than $2 \bar{y}(\bar{x}=x / H ; \bar{y}=y / H)$.

2. Sizeless vertical-plane isotachs $\bar{v}_{100}, \bar{v}_{70}, \bar{v}_{50}, \bar{v}_{30}$ and relative temperature differences $\Delta \bar{t}_{100}, \ldots, \Delta \bar{t}_{30}$ prove that air diffuser -generated non-isothermal air flow (air current) is rather stagnated at the lowest level by the floor and at the highest level by the "conventionally motionless" surrounding air. The highest relative velocities of the flow are observed at its middle altitude level, i.e. at $\bar{z}=0.5$.

3 . The experimentally defined value of initial velocity irregularity ratio is about 0.88 and that of initial temperature irregularity ratio is 0.96 .

\section{References}

[1] Staroverov, I.G. (1978). Vnutrennie sanitarno-tekhnicheskie ustroystva. Ventilyatsia $i$ konditsionirovanie vozdukha. Moscow: Stroyizdat.

[2] Grimitlin, M.I. (1982). Raspredelenie vozdukha v pomeshcheniyakh. Moscow: Stroyizdat.

[3] Poradnic.(1994). Ogrzewanie+klimatyzacja 94/95. Gdańsk.

[4] Zhukovsky, S. S., Klymenko, H. M. (2007). Konstruktsiyni osoblyvosti dzherelnykh (filtratsiynykh) povitrorozpodilnykiv i propozytsiyi shchodo ikh udoskonalennya. Naukovy visnyk: Zbirnyk naukovo-tekhnichnykh prats. Vol.17(6), pp. 101-106. Lviv: NLTUU.

[5] Zhukovsky, S.S. (1989). Ispolzovaniye priklonnykh vozdukhoraspredelitelei s tselyu ventilatsii pomeshcheniy vytesnyayushchim vozdushnym potokom . Ukraine: NIINTI.

[6] Nielsen, P.V. (1992). Velokite Distributiinthe Flowfroma Wall-Monnted Diffuserin Roomwith Displament Ventilation. In ROOMVENT'92, Third INT. Conf on Air Distribution in rooms, 1992. Aalbery, Denmark.

[7] Nielsen, P.V. (2000). Velocity. Distribution on a Room Ventilated by Displacement. 3. Ventilation and Wall-Mounted Air Terminal Devices. Energy and Building. Vol. 31(3), pp.179187.

[8] Skaret. (2000). Ventilasjnsteknik hand-bok. Handbok 48. NordesByqfork-kningsinstitut.

[9] Zhukovsky, S.S., Dobuvsh, O.M., Klymenko, H.M. (2006). Povitrorozpodilnyk. Patent № 19497. vid 15.12. 2006, Bul. № 12. Ukraina.

[10] Zhukovsky, S. S., Klymenko, H. M. (2010). Experimental and analytical research of pressure effects inside the sectional source air distributor. In Zeszyty naukowe Politechniki Rzeszowskiej. № 266. Budownictwo i inżynieriaśrodowiska, z.54, pp. 151-157.

[11] Klymenko, H.M. (2009). Tyskovi vplyvy v korpusi dvokamernoho panelnoho povitrorozpodilnyka ta zabezpechennya yihnoi rivnomirnosti. Visnyk NU LP Teoria I praktyka budivnytstva. Vyp. 655, pp. 140-147.

[12] Zhukovsky, S. S., Klymenko, H. M. (2010). Kinetychni parametry izotermichnoho strumenya sformovanoho dzherelnym panelnym dvokamernym povitrorozpodilnykom z horyzontalnopolychkovymy vyrivnyuvachamy tysku. Visnyk NU LP Teoria I praktyka budivnytstva. Vyp. 664, pp. 26-32. 